Y. ZH. GUAN ${ }^{1}$, SH. Q. LIU' ${ }^{1}$, and Y. J. ZENG ${ }^{2}$

\title{
GRADIENT TRIGGER MECHANISMS RELATED TO BISTABILITY REGIMES IN A LEECH HEARTBEAT MODEL
}

\author{
Received May 4, 2013
}

We studied bursting patterns underlied by bifurcation phenomena and chaotic spiking in a computational leech heartbeat model. We observed the gradient physical properties of the ISI trains and amplitude (shift of the membrane potential) when the parameter $\mathrm{g}_{\text {leak }}$ was mildly changed and found different bistable areas. The resulting computation implies that (i) classification of the intensity of the input information is feasible in this regime, (ii) a neuron's working level can be marked by its range in a typical bifurcation, and (iii) there are invisible triggers underlying subtle mechanisms in the model.

Keywords: leech heartbeat model, leech heart interneuron, bifurcation and chaos, leak current, injected current, interspike intervals (ISIs).

\section{INTRODUCTION}

Some general considerations on the mechanisms that provide shifting of excitable cells among different modes of multistability have been proposed, but details of such mechanisms are unknown in most cases. If we master these mechanisms, we will be able to apply the respective techniques to the treatments using biofeedback stimulation in the cases of serious illnesses. For example, we might prevent the onset of pathological regimes of seizures by returning cells of the involved networks back to the normal regime with a switch induced by stimulation treatment $[1,2]$.

In many organisms, there are central pattern generators (CPGs) comprised of neuronal circuits that generate and organize repetitive motor patterns in a few regimes. The network controlling leech heartbeat is one of the simplest examples of such networks. Control of the leech heartbeat pattern has attracted significant attention and advanced discussion. Two segmental oscillators were found in the neuronal network pacing heartbeat in the leech. They are located in the third and fourth ganglia of the ventral nerve chain $[3,4]$. In order to simulate the respective regimes, Hill et al. modeled a segmental oscillator

\footnotetext{
1 Department of Mathematics, South China University of Technology, Guangzhou, China.

${ }^{2}$ Biomedical Engineering Center, Beijing University of Technology, Beijing, China.

Correspondence should be addressed to

Y. Zh. Guan (e-mail: yzhguan@scutedu.cn) or

Y. J. Zeng (e-mail: yjzeng@bipu.edu.cn)
}

pacing heartbeat in the leech using Hodgkin-Huxley equations [5]. This model was constructed as a network of six heart interneurons localized within a single ganglion [6]. The network comprised the basic rhythm generator and demonstrated properties more similar to those of the biological prototype than the previous model [7].

Cymbalyuk et al. [7] provided diagrams for the activity of single interneurons of this model. There were three separate areas in these diagrams, (i) a bursting regime coexisting with silence, (ii) bursting coexisting with tonic spiking, and (iii) tonic spiking coexisting with silence. Shilnikov et al. [8] described the connection between a codimension of bifurcation and a transition from tonic spiking behavior to bursting behavior. Malashchenko et al. [9] pointed out the existence of a saddle periodic orbit as the main factor providing coexistence of the bursting and silent regimes.

In our study, as a further step towards understanding the relation between a single cell regime and network functions, we explore more physical properties of the leech heartbeating model, paying special attention to interspike intervals (ISIs) as one of the notable characteristics in the respective models. We investigated bursting patterns under conditions of application of electric current (DC) to the canonical leech heart interneuron model, and we also analyzed bifurcation diagrams for ISIs and amplitudes (shifts of the membrane potential) characterizing the transitions between different firing patterns with variation of the magnitude of DC fields. Equations were integrated 
using the fourth-order Runge-Kutta method. Values of the ISI(s) are a comprehensive feature for many computational results; so, these parameters may reveal some regular features beyond the biological experiments; at the same time, they may also miss some details of the pattern. Thus, we extended our investigation to the results derived from the leech heartbeat computational model and found out that mild changes in the amplitude of the above-mentioned influence (DC electric field) may determine specific diagrams of bifurcation and chaos characteristics of the firing patterns. We noticed that ISIs regularly exhibit bifurcation and chaos patterns when the model was subjected to weak electrical stimulation. This uncommon feature allowed us to deduce certain relations between properties of single neurons, neuronal behavior in the CPG network in general, that in the leech special structure in particular, and some biological phenomena (motor activity).

\section{DESCRIPTION OF THE MODEL}

Previous works $[10,11]$ revealed that there are three classes of central neurons controlling heartbeat in the leech kinetic system. The compartment of the network is formed by 14 heart interneurons (HN cells); it generates the heartbeat rhythm and controls the activity of excitatory heart motor neurons (HE cells) [12]. Furthermore, heart accessory neurons (HA cells) also receive inputs from $\mathrm{HNs}$ [13]. In general, $\mathrm{HN}$ cells are "leading" elements of the system. Figure 1 describes the synaptic connectivity in the heartbeat CPG.

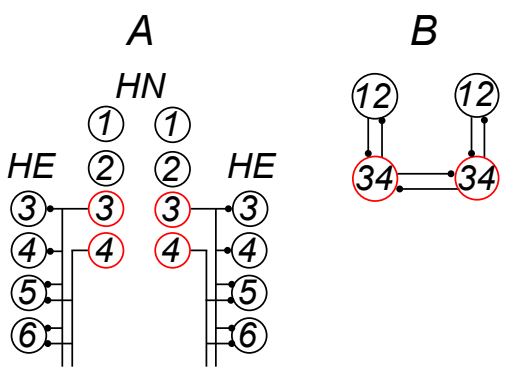

F i g. 1. Scheme of neurons and synapses in the heartbeat central pattern generator. A) Network of synaptic connections between HNs and HEs. Circles represent neurons, lines represent their connections, and filled small circles denote inhibitory chemical synapses. B) Basic oscillator built by neurons and inhibitory synapses among HN cells.

Р и с. 1. Схема нейронів і синапсів у центральному генераторі, що контролює скорочення серця.
A single heart interneuron was modeled [6] based on Hodgkin-Huxley equations [5] including intrinsic and synaptic conductances of the HN cells. The respective oscillations (changes in the amplitude, i.e., in values of the membrane potential), especially those typical of the bursting pattern, are similar in their form to oscillations observed in the biological system. [7]. In Fig. 1, the locations of interneurons in this model are shown.

The model involves the following currents: fast calcium current, slow calcium current, fast sodium current, delayed-rectifier potassium current, persistent potassium current, fast transient potassium current, hyperpolarization-activated cationic current, persistent sodium current, and leak current. These currents are described by a system of 14 differential equations.

$$
\begin{aligned}
& C V^{\prime}=\vec{g}_{N a} m_{N a}^{3} m_{N a}^{3} h_{N a}\left(E_{N a}-V\right)+\vec{g}_{P} m_{P}\left(E_{N a}-V\right)+ \\
& +\vec{g}_{K I} m_{K I}^{2} h_{K 1}\left(E_{K}-V\right)+\vec{g}_{K 2} m_{K 2}^{2}\left(E_{K}-V\right)+ \\
& +\vec{g}_{K A} m_{K A}^{2} h_{K A}\left(E_{K}-V\right)+\vec{g}_{C a S} m_{C a S}^{2} h_{C a S}\left(E_{C a}-V\right)+ \\
& +\vec{g}_{C a F} m_{C a F}^{2} h_{C a F}\left(E_{C a}-V\right)+\vec{g}_{h}\left(E_{h}-V\right)+ \\
& +g_{\text {leak }}\left(E_{\text {leak }}-V\right)+I_{i n j} .
\end{aligned}
$$

The values corresponding to the model parameters in Eq. (1) have been adopted from the communication by Hill et al. [6]. All parameters including $E_{\text {leak }}$ were set to the canonical values; only the $g_{\text {leak }}$ was set from 11.3 to $12.9 \mathrm{nS}$ in the following analysis.

\section{SIMULATION RESULTS RELATED TO BIFURCATION AND CHAOS PHENOMENA}

Sequences of action potentials (APs) in bifurcation and chaos modes. The bursting regime and its relation to physical parameters of the neurons are of high physiological significance in the processing of information by neuronal networks $[14,15]$. We do not discuss the special problem of how the bursting AP organization influences the target cells, as compared with the effects of regular rhythmic spiking; this aspect is beyond the topic of our communication. The complexity of dynamical regimes of spiking interferes with clear understanding of the respective mechanisms responsible for one type or another of biological behavior. The fast/slow analysis [16-19] became an extensively accepted method for recognizing several typical bursting patterns in neuronal networks. In a 

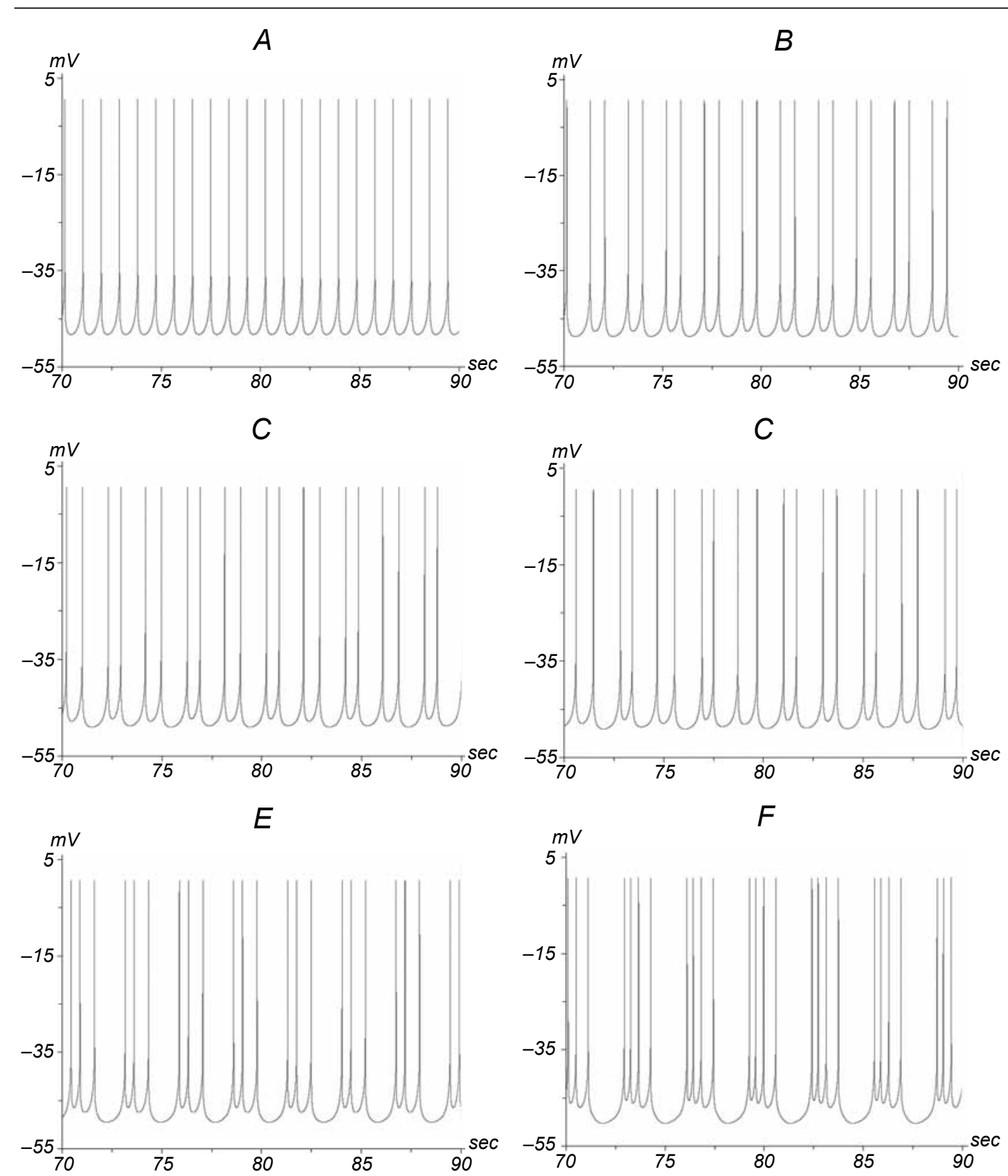

F i g. 2. Patterns of spiking produced by the model neuron. A) Tonic spiking, B and C) bursts consisting of two spikes, D) bursting with a varied number of spikes and unstable interspike intervals (chaos), E and F) bursting with three and four spikes, respectively. $g_{\text {leak }}=12.7 \mathrm{nS}$; injected direct current $\left(I_{i n j}\right)=0.017,0.0159,0.0154,0.015,0.0145$, and $0.0126 \mathrm{nA}$ in A-F, respectively.

Р и с. 2. Патерни імпульсної активності, генерованої модельним нейроном.

single neuron, different currents interplay and provide the coexistence of different types of firing activity (known as regular spiking, bursting, silence, and oscillations) [20-22].

We firstly exhibited some typical sequences of APs for characterization of HN neurons in our model and focused on the bursting patterns underlied by bifurcation phenomena and chaos spiking. Bursting patterns produced by the model neuron are shown in Fig. 2. In this case, the $g_{\text {leak }}$ was constant and equal to $12.7 \mathrm{nS}$, while the injected direct current $I_{i n j}$ was changed (A-F).

As is well known, the frequency, period, and duty cycle of bursting are important physical properties for firing patterns of neurons in fast/slow systems. Undoubtedly, we can use these indices to summarize 

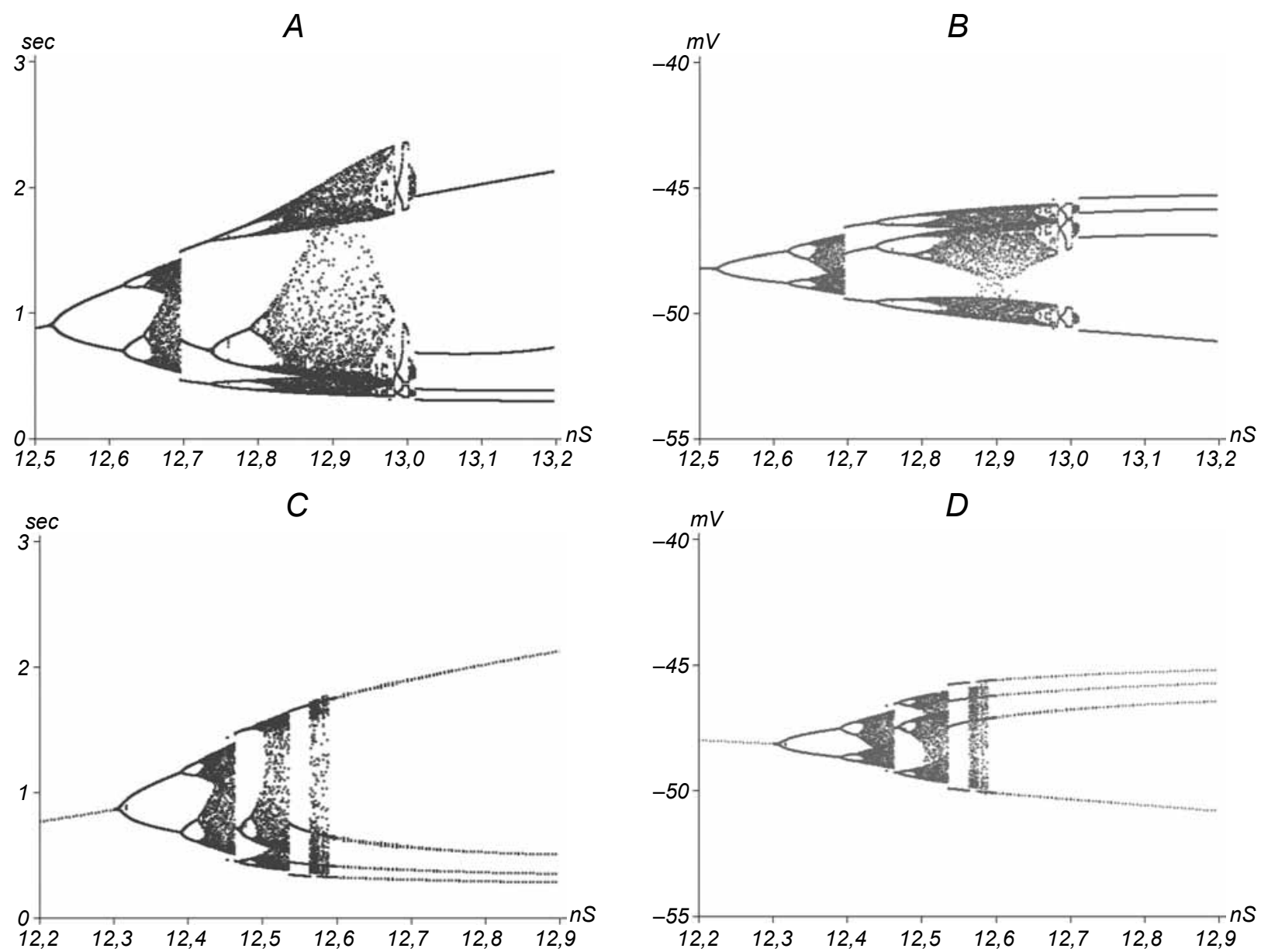

F i g. 3. Scatter plots for the relations between ISIs, sec, and $g_{\text {leak }}, \mathrm{nS}(\mathrm{A}$ and $\mathrm{C})$ and between the amplitude, $\mathrm{mV}$, and $g_{\text {leak }}, \mathrm{nS},(\mathrm{B}$ and $\mathrm{D})$. In $\mathrm{A}$ and $\mathrm{B}, g_{\text {leak }}=12.5$ to $13.2 \mathrm{nS}, I_{i n j}=0.0147 \mathrm{nA}$; in C and D, $g_{\text {leak }}=12.2$ to $12.9 \mathrm{nS}, I_{i n j}=0.0121 \mathrm{nA} ; E_{\text {leak }}=-0.061 \mathrm{mV}$ in all cases.

Р и с. 3. Діаграми розсіяння для відношень між тривалістю міжімпульсних інтервалів, с, та $g_{\text {leak }}$, нСм, $(A$ та $C)$ i між амплітудою, мВ, та $g_{\text {leak }}$, нСм (B та $D$ відповідно).

information on the pattern from biological results to physical features, allowing us to correlate firing behavior of the neuron with transition behavior of the network. Although it is difficult to explain directly the animal's biological patterns by description of the respective micromechanisms till now, it is a promising branch for understanding the regimes of neuronal activity. The bursting patterns in Fig. 2 demonstrate that the ISI groupings vary from one to two, two to three, and so on. This phenomenon means that bifurcation occurs. We explore more physical properties to reveal the biological process, such as ISI sequences and amplitudes (shifts of the membrane potential).

Gradient mechanisms across bistability regimes. The previous study on the leech heartbeat $\mathrm{HN}$ neuron model showed that the bistability of bursting and silence is associated with the Andronov-Hopf bifurcation [7]. This implies that the barrier separating two attractors, bursting and silence, is the stable manifold of a saddle periodic orbit [9]. Below, we show preview diagrams (scatter plots) demonstrating the interrelation between ISIs and values of the amplitude and $g_{\text {leak }}$.

Hill et al. [6] found that an increase in the maximum conductance for the leak current $\left(g_{\text {leak }}\right)$ leads to decreases in the cycle period and spike frequency. Cymbalyuk et al. [7] showed bifurcation diagrams for a single cell and pointed out three coexisting areas, bursting and silence, bursting and tonic spiking, and tonic spiking and silence. Shilnikov et al. [8] demonstrated that bifurcation of a codimension can explain the transition between tonic spiking behavior and bursting behavior. Malashchenko et al. [9] showed that the main factor for a regime of coexistence of bursting and silence is a saddle periodic orbit. 

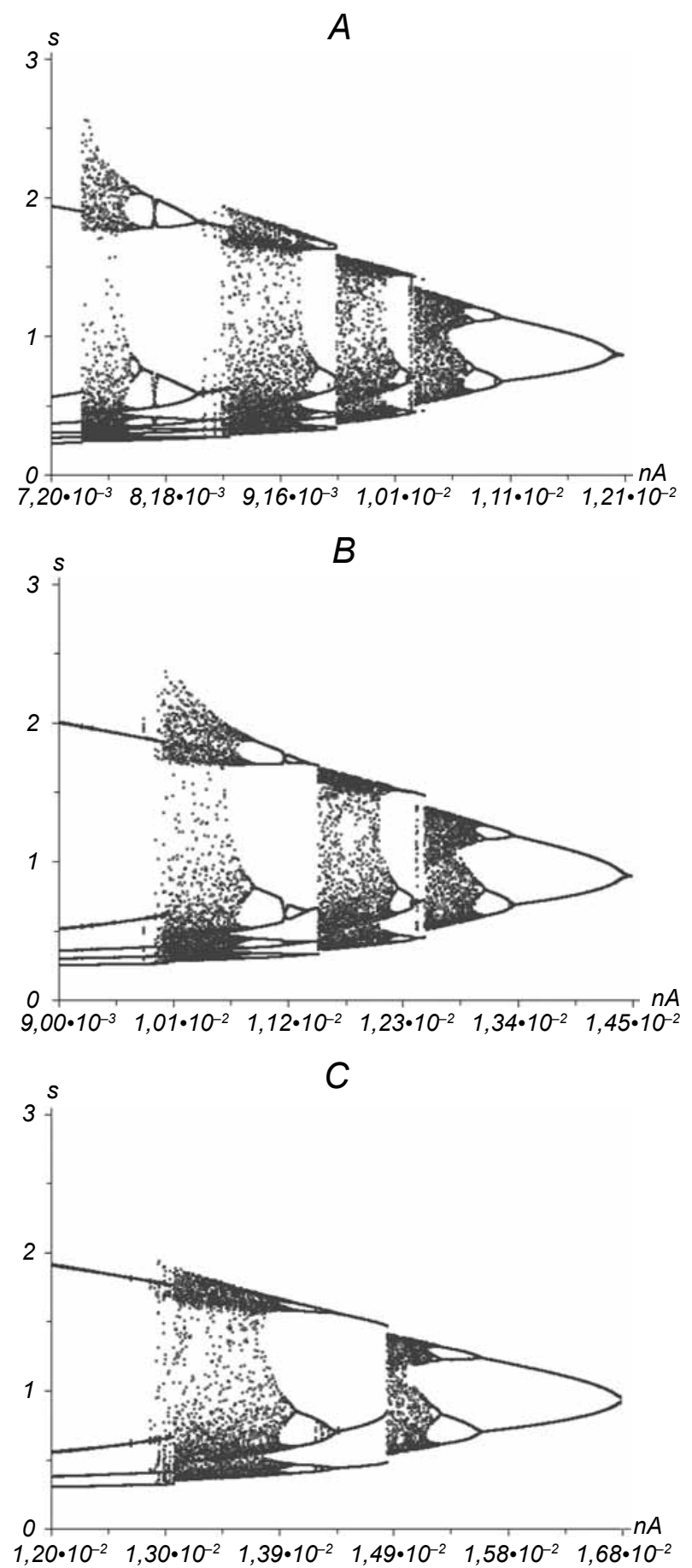

F i g. 4. Scatter plots for the dependence between ISIs, sec, and $I_{i n j}, \mathrm{nA}$. In A $-\mathrm{C}, g_{\text {leak }}=12.3,12.5$, and $12.7 \mathrm{nS}$, respectively.

Р и с. 4. Діаграми розсіяння для залежності між тривалістю міжімпульсних інтервалів (с) та $I_{i n j}($ нА).

We discovered in more detail the influence of the $g_{\text {leak }}$ values across different areas [7] including gradient physical properties for ISIs, in particular a nadir of the amplitude. In particular, the peak of the amplitude appears almost along a horizontal line. We believe that this is an uncommon physical characteristic in the neuronal models. When we compare Fig. 3 A and $\mathrm{C}$ vs. $\mathrm{B}$ and $\mathrm{D}$ in groups, we find that different injection current intensities underlie the gradient structure variation. This implies that (i) the neuron can "recognize" the intensity of the input "information", (ii) the neuron can "inform" other units with respect to its working level by its range in bifurcation, and (iii) there are invisible triggers existing in the mechanisms of the bistability regimes for this model. It might help us to understand why some phenomenon appears or disappears unpredictably.

ISI and amplitude bifurcation reveals trigger details in the gradient mechanisms. Since the Lapicque formula approximates well the strengthduration physical law under the action of square pulse stimulation current [9], we believe that we can reveal some physical properties related to the biological features in this computation model. As before, we recognized bifurcation in Fig 2; when we increase or decrease the $g_{\text {leak }}$ variable, bifurcation appears as the fitting of the complete section of the injected current. We illustrate the ISI, $I_{i n j}$, and $g_{\text {leak }}$ interdependence by diagrams (scatter plots) in Fig 4. The settings of $g_{\text {leak }}$ varied between 12.3 and $12.7 \mathrm{nS}(\mathrm{A}-\mathrm{C})$.

It is interesting that bifurcation in A changes from two to four, but that from three to six follows. In $\mathrm{B}$, bifurcation changes from two to four, three to six follows, and four to eight occurs finally. In $\mathrm{C}$, bifurcation occurs as in $\mathrm{B}$ and finally from five to ten. As we increase the variable, the law determining bifurcation develops as a linear and double-interlaced increase.

The diagram of the amplitude shows that the peak of the amplitude is located along the horizontal line, and a trend toward the bottom is not clear. Once we amplify the nadir of the amplitude only in our plane rectangular coordinate system, bifurcation emerges. We illustrate the respective three diagrams in Fig 5. The $g_{\text {leak }}$ settings are the same as in Fig 4, i.e., 12.3, 12.5 , and $12.7 \mathrm{nS}$ (A-C, respectively).

Comparison of Figs. 4 and 5 shows that these panels display similar patterns as those that we predicted before, including the law described in the Discussion and location of the bifurcation beginning in the next Fig. 6. When we explored the detailed transition modes in Fig. 5, we were surprised that, instead of the "divergence" property of ISIs, the nadir of the amplitude displays some "convergence" properties. In Fig. 4, when we follow the tracks of the outward 

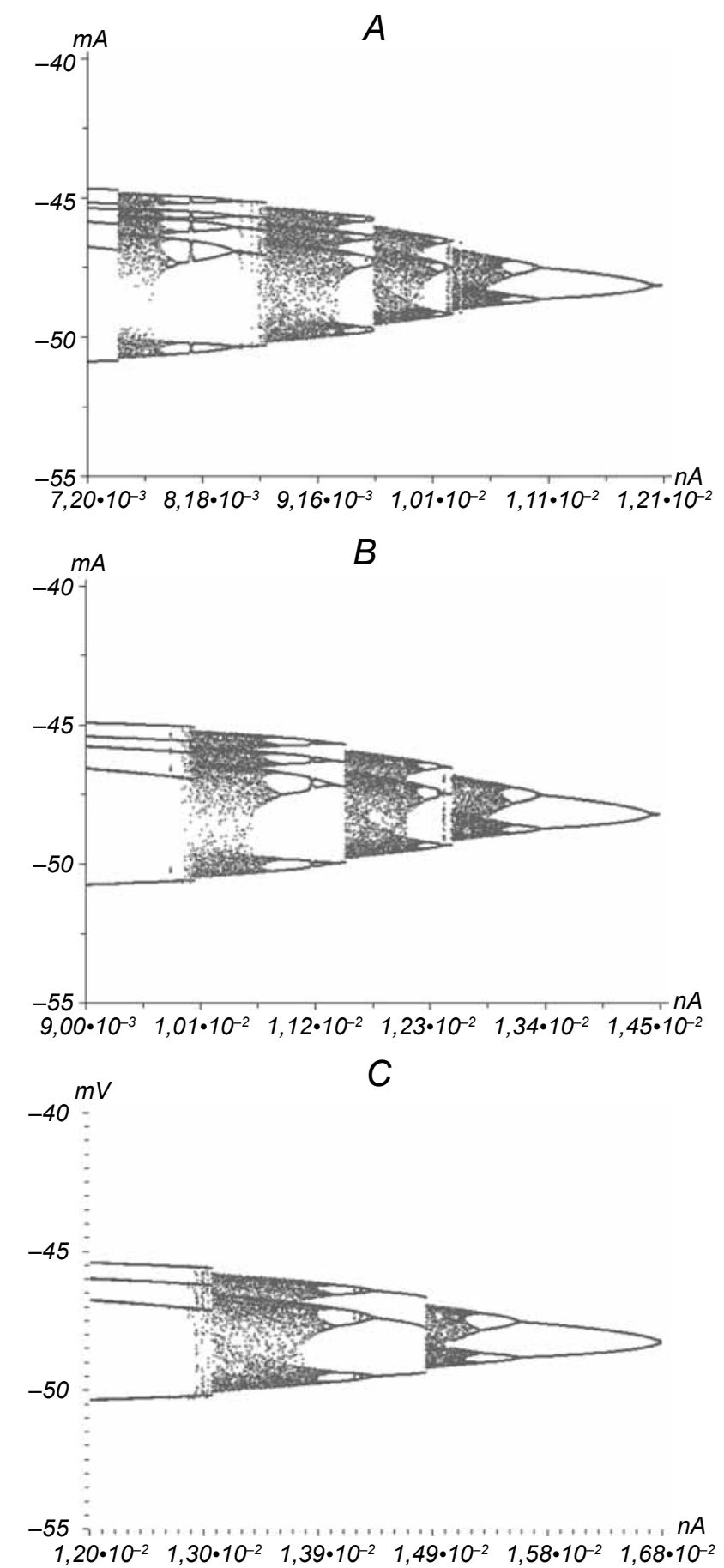

F i g. 5. Scatter plots for the dependence between the amplitudes (changes in the membrane potential), $\mathrm{mV}$, and $I_{i n j}, \mathrm{nA}$. In $\mathrm{A}-\mathrm{C}$, $g_{\text {leak }}=12.3,12.5$, and $12.7 \mathrm{nS}$, respectively.

P и с. 5. Діаграми розсіяння для залежності між амплітудою (зміною мембранного потенціалу, мВ) та $I_{i n j}($ нА).

bifurcation, we cannot be sure whether the point is inside the range or not. The situation means that if we can build a mathematical model for outward

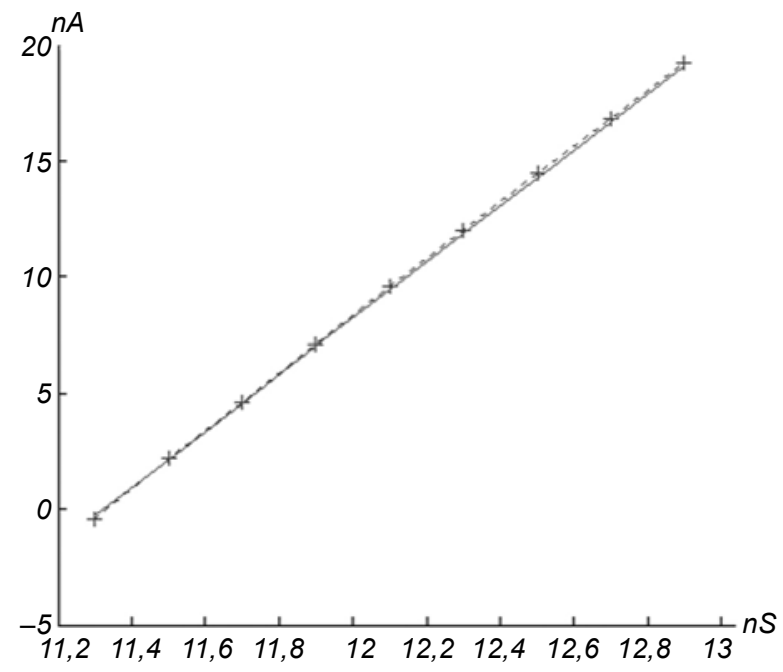

F i g. 6. Graph of the dependence between $g_{\text {leak }}$ and $I_{i n j}$ for the bifurcation position.

Р и с. 6. Графік залежності між $g_{l e a k}$ та $I_{i n j}$, що визначає положення біфуркації.

bifurcation, all points are surely to be localized inside the domain.

Relation between the injected current intensity and trigger mechanisms. We notice that the location of the bifurcation moves to opposite directions, while the stimulation influence is manifested in a monotonic increase or decrease. The trail of bifurcation looks like a tree in Figs. 4 and 5. So, we choose the "root" value to mark the location of bifurcation. This means that we used the value of the current mostly at the right side in Figs. 4 and 5. We computed nine points where the $g_{\text {leak }}$ changed from 11.3 to $12.9 \mathrm{nS}$. We used MATLAB to plot the points, and the points are connected by a broken line. The result is shown in Fig. 6.

It is obvious that there is a linear relationship between the $g_{\text {leak }}$ and the location. We developed a formula for fitting [Eq. (2)]. As $g_{\text {leak }}$ increases, the injected current must be increased so that ISI and amplitude bifurcation can be found in a region shifted toward the less intense current. The linear regression formula looks like:

$$
I_{i n j}=0.0121 \cdot g_{\text {leak }}-0.137
$$

\section{DISCUSSION}

We focused on the bursting patterns underlied by the bifurcation phenomenon or chaotic impulsation in the model used (Fig. 2). As was demonstrated, ISI groupings vary from one to two, two to three, and so 
on. We recognized that this phenomenon means the existence of bifurcations. Thus, we explored more model physical properties to reveal the biological parameters, such as ISI durations and amplitude (in Fig. 3). We discovered more details during changing the $g_{\text {leak }}$ across different areas [7] for the gradient physical properties for ISIs (in Fig. 4) and the nadir of the amplitude (in Fig. 5). We ignore the fact that the peak of the amplitude appears almost along the horizontal line, though it is an unexpected physical characteristic in the model of the neuron. The result of computation implies that (i) the neuron can "recognize" the intensity of the input "information," (ii) the neuron can "tell" others about its working level by its range for bifurcation, and (iii) there are invisible triggers that exist in the mechanisms of bistability regimes for this model. These findings might explain why some phenomenon appears or disappears unpredictably. In addition, we provided the locations where the bifurcation begins and found a linear dependence between the injected current and the examined parameter, independently of the coefficients in Eq. (1).

Acknowledgment. This work was supported by the National Natural Science Foundation of China (Grant No. 11172103).

The authors, Y. Zh. Guan, Sh. Q. Liu, and Y. J. Zeng, confirm that they have no conflict of interest.

\section{Ї. Ж. Гуан}

ГРАДІСНТНІ ТРИГЕРНІ МЕХАНІЗМИ, ПОВ'ЯЗАНІ 3 РЕЖИМАМИ БІСТАБІЛЬНОСТІ, В МОДЕЛІ КОНТРОЛЮ СЕРЦЕВИХ СКОРОЧЕНЬ У П’ ЯВКИ

${ }^{1}$ Південно-китайський технологічний університет, Гуанчжоу (Китай).

${ }^{2}$ Пекінський технологічний університет (Китай).

Р е 3 ю м е

Ми досліджували пачкові імпульсні патерни, що формувалися на основі феноменів біфуркації, та хаотичну імпульсну активність у комп'ютерній моделі керування серцевими скороченнями у п'явки. Ми спостерігали градієнтність фізичних властивостей, що визначали характеристики послідовностей імпульсів та амплітуду (зміщення мембранного потенціалу), при невеликих змінах параметра $g_{\text {leak }}$ (провідності витоку). Було також виявилено, що існують різні зони бістабільності. Результати комп'ютерного моделювання вказують на те, що, по-перше, в такому режимі може за- безпечуватися класифікація інтенсивності вхідної інформації; по-друге, робочий рівень для нейрона визначаеться його положенням у типовій біфуркації, i, по-третє, існують «невидимі» тригери, на яких базуються тонкі механізми моделі.

\section{REFERENCES}

1. P. Suffczynski, S. Kalitzin, and F. H. Lopes da Silva, "Dynamics of non-convulsive epileptic phenomena modeled by a bistable neuronal network," Neuroscience, 126, No. 2, 467-484 (2004).

2. P. A. Tass and C. Hauptmann, "Therapeutic modulation of synaptic connectivity with desynchronizing brain stimulation," Int. J. Psychophysiol., 64, No. 1, 53-61 (2007).

3. E. L. Peterson, "Generation and coordination of heartbeat timing oscillation in the medicinal leech. I. Oscillation in isolated ganglia," J. Neurophysiol., 49, No. 3, 611-626 (1983).

4. E. L. Peterson, "Generation and coordination of heartbeat timing oscillation in the medicinal leech. II. Intersegmental coordination," J. Neurophysiol., 49, No. 3, 627-638 (1983).

5. A. L. Hodgkin and A. F. Huxley, "A quantitative description of membrane current and its application to conduction and excitation in nerve," J. Physiol., 117, No. 4, 500-544 (1952).

6. A. A. Hill, J. Lu, M. A. Masino, et al., "A model of a segmental oscillator in the leech heartbeat neuronal network," J. Comput. Neurosci., 10, No. 3, 281-302 (2001).

7. G. S. Cymbalyuk, Q. Gaudry, M. A. Masino, and R. L. Calabrese, "Bursting in leech heart interneurons: cell autonomous and network based mechanisms," J. Neurosci., 22/24, 1058010592 (2002).

8. A. Shilnikov, R. L. Calabrese, and G. Cymbalyuk, "Mechanism of bistability: Tonic spiking and bursting in a neuron model," Phys. Rev. E, 71, 056214 (2005).

9. T. Malashchenko, A. Shilnikov, and G. Cymbalyuk, "Bistability of bursting and silence regimes in a model of a leech heart interneuron," Phys. Rev. E, 84, 041910 (2011).

10. E. A. Arbas and R. L. Calabrese, "Ionic conductances underlying the activity of interneurons that control heartbeat in the medicinal leech," J. Neurosci., 7, No. 12, 3945-3952 (1987).

11. E. A. Arbas and R. L. Calabrese, "Slow oscillations of membrane potential in interneurons that control heartbeat in the medicinal leech," J. Neurosci., 7, 3953-3960 (1987).

12. W. J. Thompson and G. S. Stent, "Neuronal control of heartbeat in the medicinal leech. II. Intersegmental coordination of heart motor neuron activity by heart interneurons," J. Comp. Physiol., 111, 281-307 (1976)

13. R. L. Calabrese and A. R. Maranto, "Neural control of the heart in the leech, Hirudo medicinalis. III. Regulation of myogenicity by heart accessory neurons," J. Comp. Physiol., 154, 393-406 (1984).

14. J. E. Lisman, "Bursts as a unit of neural information: Making unreliable synapses reliable," Trends Neurosci., 20, No. 1, 3843 (1997).

15. E. M. Izhikevich, "Neural excitability, spiking and bursting," Int. J. Bifurc. Chaos, 10, No. 6,: 1171-1266 (2000).

16. J. Rinzel and Y. S. Lee, "Dissection of a model for neuronal parabolic bursting," J. Math. Biol., 25, No. 6, 653-675 (1987).

17. A. Sherman and J. Rinzel, "Rhythmogenic effects of weak electrotonic coupling in neuronal models," Proc. Natl. Acad. 
Sci. USA, 89, No. 6, 2471-2474 (1992).

18. E. Av-Ron, H. Parnas, and L. A. Segel, "A basic biophysical model for bursting neurons," Biol. Cybern., 69, No. 1, 87-95 (1993).

19. M. E. Rush and J. Rinzel, "Analysis of bursting in a thalamic neuron model." Biol. Cybern., 71, No. 3, 281-291(1994).

20. J. Hounsgaard and O. Kiehn, "Serotonin-induced bistability of turtle motoneurones caused by a nifedipine-sensitive calcium plateau potential," J. Physiol., 414, 265-282 (1989).

21. P. Fuentealba, I. Timofeev, M. Bazhenov, et al., "Membrane bistability in thalamic reticular neurons during spindle oscillations, " J. Neurophysiol., 93, No. 1, 294-304 (2005).

22. Y. Loewenstein, S. Mahon, P. Chadderton, et al., "Bistability of cerebellar Purkinje cells modulated by sensory stimulation." Nat. Neurosci., 8, 202-211(2005). 